\title{
Molecular definition of the Prader - Willi syndrome chromosome region and orientation of the SNRPN gene
}

\author{
Karin Bulting, Bärbel Dittrich, Stephanie GroB, Valerle Greger ${ }^{1}$, Marc Lalande', Wendy Robinson ${ }^{2}$, \\ Aplwat Mutirangura ${ }^{3,+}$, David Ledbetter ${ }^{3}$ and Bernhard Horsthemke ${ }^{*}$ \\ Institut für Humangenetkk, Unwerstätsklinkum Essen, Hưfelandstrasse 55, D-45122 Essen, Germany, 'The Howard Hughes Instutute and The Chuldren's Hospital, Boston, \\ MA, USA, 2Instutut für Medizanische Genetık, Zürich, Switzerland and BBaylor College of Medicine, Hourston, TX, USA
}

Received August 31, 1993; Revised and Accepted October 14, 1993

The Prader - Will syndrome and the Angelman syndrome are caused by the loss of functlon of distinct but closely linked genes on human chromosome 15. Based on a yeast artiflclal chromosome restriction map and two key patients we have determined that the shortest region of deletion overlap in the Prader - Will syndrome comprises $320 \mathrm{~kb}$. The reglon Includes the anonymous DNA marker PW71 (D15S63) and the gene for the small nuclear ribonucleoprotein N (SNRPN). The SNRPN gene maps $130 \mathrm{~kb}$ distal to PW71 and is transcribed from centromere to telomere.

\section{INTRODUCTION}

The Prader - Willi syndrome (PWS) and the Angelman syndrome (AS) are distinct neurogenetic disorders, which are caused by the loss of function of closely linked genes on chromosome 15 . Paternal deletions and maternal disomy in PWS suggest that the PWS gene(s) are transcribed from the paternal chromosome only. Likewise, maternal deletions and paternal disomy in AS suggest that the AS gene(s) are transcribed from the maternal chromsome only (for review see reference 1 ).

About $60 \%$ of patients with PWS and AS have a deletion that includes all the loci from ML34 (D15S9/ZNF127) to IR10 (D15S12/P) (Fig. 1). A complete YAC contig spanning this region has recently been developed (2). Robinson et al. (3) have described a unique PWS patient (PW93), who is deleted for a subset of these loci only. The proximal deletion breakpoint in this patient is between 189-1 (D15S13) and PW71 (D15S63) and currently defines the proximal boundary of the PWS region. Saitoh et al. (4) have described a Japanese family in which a deletion encompassing 3-21 (D15S10), LS6-1 (D15S113) and GABRB3 causes AS when transmitted through the female germline, but is without phenotype when transmitted through the male germline. Thus, the proximal deletion breakpoint in this family defines the distal boundary of the PWS region. A genomic DNA fragment spanning this boundary has recently been cloned (B1.5, D15S174) (5).

The PWS region includes the anonymous DNA marker PW71, which shows parent-of-origin specific DNA methylation (6), and the gene for the small nuclear ribonucleoprotein protein $\mathbf{N}$ (SNRPN), which has been proposed as a candidate gene for PWS (7). Based on yeast artificial chromosome clones (8) we have determined the size of this region and constructed a detailed physical map.

\section{RESULTS}

Five yeast artificial chromosome clones (YACs) were analyzed. YAC B58C7 had been identified with probe PW71. The left end of this YAC contains non-chromosome 15 DNA. The right end of this YAC was used to isolate YACs $11 \mathrm{H} 11,309 \mathrm{G} 7,326 \mathrm{~F} 6$, and 457B4 (8). Total yeast DNA was digested with the rare cutter enzymes SacII, Sall and NotI and separated by pulsed field gel electrophoresis. Southern blots were hybridized with total human DNA to detect all restriction fragments, with appropriate pBR322 fragments to detect $\mathrm{YAC}$ end fragments (9) and with several unique probes from this region (Table 1 ).

The restriction enzyme analysis revealed $3 \mathrm{SacI}$ sites, 2 Sall sites and 2 NotI sites. As shown in Fig. 2, YAC 326F6 spans 189-1 and PW71. These loci are separated by a $180 \mathrm{~kb} \mathrm{SacII}$ fragment. YACs 1.1H11 and 309G7 span PW71 and SNRPN. YAC B58C7 is positive for PW71 only and YAC 457B4 is positive for SNRPN only. A subclone from YAC B58C7, which maps $3 \mathrm{~kb}$ telomeric to $\mathrm{PW} 71$ and contains a long terminal repeat (LTR) (see accompanying paper by Dittrich et al., (10)), detects an abnormal HindIII fragment in YAC 457B4 (not shown). This indicates that the right end of YAC 457B4 maps very close to PW71.

Another subclone from B58C7 (p71.19.11, (10)) and an interAlu PCR clone (p9.2) were tested. Both probes identify a 180 kb SacII fragment in YAC 326F6 and a 95 kb SacII fragment in YAC B58C7. This indicates that 9.2 and 71.19.11 map centromeric to the SacII site in YAC B58C7. PW71 identifies a $30 \mathrm{~kb}$ SacII fragment and thus maps telomeric to this site.

The proximal deletion breakpoint in patient PW93 had been mapped to the region between 189-1 and PW71 (3). For localizing this breakpoint more precisely we hybridized 9.2 and 71.19.11 to HindIII digested DNA from this patient. MetD was used as

\footnotetext{
* To whom correspondence should be addressed

+ Present address: Department of Anatomy, Faculty of Medicine, Chulalongkom University, Bangkok 10330, Thailand
} 


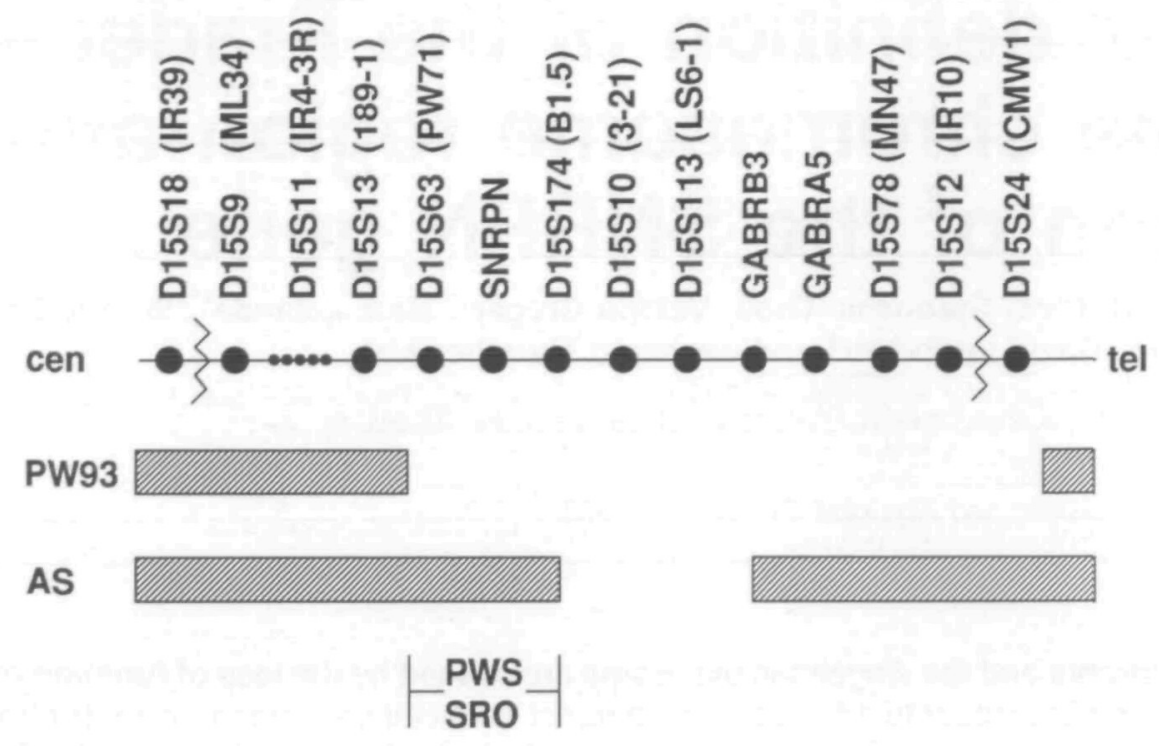

Figure 1. Locus order in 15q11-13. The wavy lines indicate the common deletion breakpoints in AS and PWS. The chromosome regions which are intact in the PWS patient PW93 (2) and the Japanese AS family (3) are indicated by hatched bars. The distance between the loci are not drawn to scale. SRO, shortest region of deletion overlap.

an internal hybridization standard. Densitometric analysis revealed two copies of 9.2 (not shown). 71.19 .11 , which maps between 9.2 and PW71, detects HindIII, BclI and $B g l I$ deletion junction fragments in the patient (Fig.3). The detection of an abnormal HindIII fragment by 71.19 .11 , which is a 600 bp Sau3A-HindIII (cen $\rightarrow$ tel) fragment (10), indicates that 71.19.11 spans the proximal deletion breakpoint in PW93.

Probe B1.5 (D15S174), which defines the distal boundary of the PWS region (5), maps to a $60 \mathrm{~kb} S a l$ fragment from the left (telomeric) end of YAC 457B4. Since the corresponding fragment from YAC $309 \mathrm{G} 7$ is $50 \mathrm{~kb}$ and negative for $\mathrm{B} 1.5$, this marker maps within $10 \mathrm{~kb}$ from the genomic end of YAC 457B4. Based on this result and the localization of the PW93 deletion breakpoint we can estimate that the PWS region is approximately $320 \mathrm{~kb}$.

Analysis of the YAC clones with NotI revealed two sites: one $170 \mathrm{~kb}$ centromeric to PW71 and one $130 \mathrm{~kb}$ telomeric to PW71. The latter site most probably corresponds to the NotI site present at the 5' end of the SNRPN cDNA (11). Using a brain cDNA library and appropriate PCR primers, we amplified the SNRPN cDNA sequence $3^{\prime}$ to the NorI site. This fragment hybridizes to the telomeric NotI fragments of YACs 11H11, 309G7 and 457B4. This indicates that the SNRPN gene maps approximately $130 \mathrm{~kb}$ telomeric to PW71 and is transcribed from centromere to telomere.

\section{DISCUSSION}

Based on a YAC restriction map and two key patients we have determined that the shortest region of deletion overlap in PWS currently comprises $320 \mathrm{~kb}$. The region includes the SNRPN gene, which in mice is subject to genomic imprinting (12). This makes SNRPN a good candidate gene for at least some of the features of PWS. By anchoring the gene to a Notl site, which may be part of a $\mathrm{CpG}$ island, we have determined that the direction of transcription is from centromere to telomere.
Table 1. YAC restriction fragments

\begin{tabular}{|c|c|c|c|c|}
\hline YAC clone & sixt & $\begin{array}{l}\text { Enzyme } \\
\text { Sall }\end{array}$ & Sachl & Nor \\
\hline $326 \mathrm{~F} 6$ & $300 \mathrm{~kb}$ & 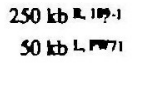 & $\begin{array}{l}180 \mathrm{~kb} \cdot 1 \\
70 \mathrm{~kb} \times 10-1 \\
50 \mathrm{~kb} \text { L.m }\end{array}$ & $\begin{array}{l}220 \mathrm{~kb} \\
80 \mathrm{~kb}\end{array}$ \\
\hline $11 \mathrm{H} 11$ & $420 \mathrm{~kb}$ & 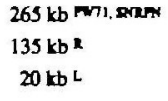 & 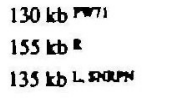 & $\begin{array}{l}155 \mathrm{~kb} \text { shem } \\
265 \mathrm{~kb}\end{array}$ \\
\hline 30907 & $440 \mathrm{~kb}$ & 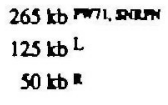 & 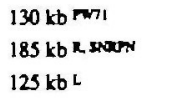 & $\begin{array}{l}185 \mathrm{~kb} \text { stam } \\
255 \mathrm{~kb}\end{array}$ \\
\hline B58C7 & $125 \mathrm{~kb}$ & $\begin{array}{l}95 \mathrm{~kb} L \\
30 \mathrm{~kb} / \mathrm{mm}\end{array}$ & $\begin{array}{l}95 \mathrm{~kb} L 9.2 \\
30 \mathrm{~kb} \times \mathrm{m}, \mathrm{m} /\end{array}$ & $125 \mathrm{~kb}$ \\
\hline 457B4 & $315 \mathrm{~kb}$ & $\begin{array}{l}255 \mathrm{~kb} \text { le, nam } \\
60 \mathrm{~kb} \text { L. } 11 \mathrm{~s}\end{array}$ & $\begin{array}{l}195 \mathrm{~kb} \text { L. momet, als } \\
120 \mathrm{~kb} \text { k }\end{array}$ & $\begin{array}{l}195 \mathrm{~kb} \text { and } \\
120 \mathrm{~kb}\end{array}$ \\
\hline
\end{tabular}

Restriction fragments were detected by hybridization with total human DNA, unique probes (indicated by superscripts) and pBR322 fragments for the right (R) and left (L) YAC ends. NotI digests were hybridized with total human DNA and SNRPN only. Probes 9.2 and 71.19.11 were used on SacI digested DNA of YACs $326 \mathrm{~F} 6$ and $\mathrm{B} 58 \mathrm{C} 7$ only.

The PWS SRO is large enough to contain many more genes beside SNRPN. Apart from a Sall and SacII site close to PW71, however, there is no indication for another CpG island in this region. It is possible that most of the genes in this region lack such islands. YAC 457B4, which spans most of the PWS SRO, will be a useful tool to search for additional genes. A good candidate region for gene sequences is the PW71 locus, which displays parent-of-origin specific DNA methylation (5). It contains a 'solo' LTR, which may promote the expression of a nearby gene (10). 

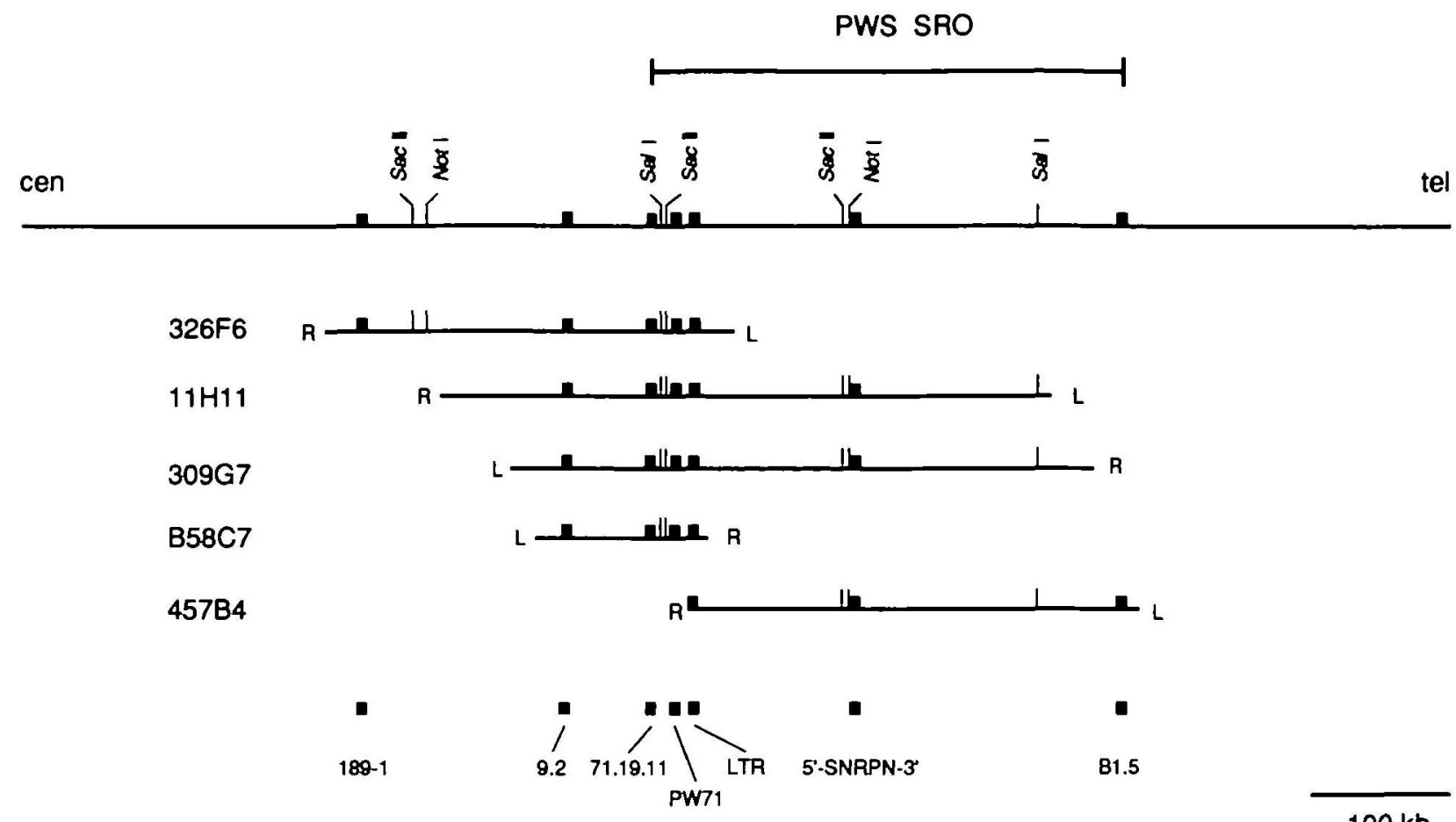

$100 \mathrm{~kb}$

Figure 2. Restriction map of the PWS SRO. The restriction map was constructed from the data shown in table 1. The exact position of $189-1$ and 9.2 within the indicated restriction fragments are unknown.

The fact that no PWS patient with a SNRPN point mutation has been described to date may indicate that the loss of function of the SNRPN gene is not sufficient for typical PWS. It is possible that the development of the full PWS phenotype requires the loss of additional genes. It should be noted that these genes may not necessarily map to the shortest region of deletion overlap. Glenn et al. (13) and Reis et al. (Reis, A., Dittrich, B., Greger, V., Buiting, K., Lalande, M., Gillessen-Kaesbach, G., Anvret, M. and Horsthemke, B., in preparation) have described AS and PWS patients who appear to have normal chromosomes of biparental origin but abnormal methylation patterns at the ZNF127/D15S9 and the D15S63 loci. Furthermore, these authors have obtained evidence for long range position effects of chromosomal rearrangements on the methylation pattern of these loci. Thus, it may ultimately be necesssary to generate a complete transcription map of 15q11-13 and to study the expression of these genes.

\section{MATERIAL AND METHODS}

\section{Pulsed field get electrophorests}

High molecular weight yeast DNA in agarose plugs was prepared as described by Carle and Olson (14). After digestion with the appropriate enzymes, DNA fragments were separated by transverse alternating field electrophoresis (TAFE, Beckman Instruments) in $10 \mathrm{mM}$ Tris/HCl/0.5 mM EDTA (free acid) $/ 4.4 \mathrm{mM}$ acetic acid, $\mathrm{pH}$ 8.2. Running conditions were $\mathrm{lhr}$ with $4 \mathrm{sec}$ pulses at $170 \mathrm{~mA}$ followed by $20 \mathrm{hr}$ with $25 \mathrm{sec}$ pulses or $18 \mathrm{hr}$ with $10 \mathrm{sec}$ pulses at $150 \mathrm{~mA}$. Saccharomyces cerevisae chromosomes (strain AB1380), lambda-concatemere from lambda Sam 7 and lambda DNA digested with HindIII were used as size markers. Southern blots were prepared and hybridized as described (15). The final wash was usually at $65^{\circ} \mathrm{C}$ in $300 \mathrm{mM}$ sodium chloride $/ 30 \mathrm{mM}$ sodium citrate $(2 \times S S C)$ containing $0.1 \%$ SDS.

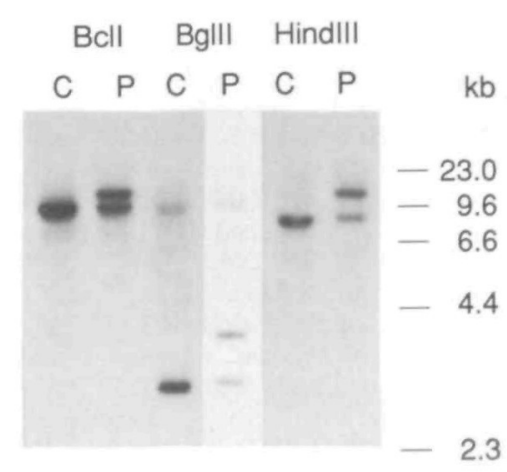

Ftgure 3. Proximal deletion breakpoint in patient PW93. DNA samples from PW93 (P) and a normal control (C) were digested with Bcll, BgIII and HindIII and probed with 71.19.11. The probe detects deletion junction fragments in the patient. The size markers were generated by HindII digestion of lambda DNA.

\section{DNA probes}

PW71, 189-1 and B1.5 have been described before $(16,17,5)$. BR322R and BR322L are pBR322 fragments that detect the right and left ends of the YAC vector, respectively (9). MetD, a probe from chromosome 7, was used as an internal standard. 71.19.11 is a genomic subclone from YAC B58C7 isolated by Dittrich et al. (10). 9.2 is an inter-alu-PCR product amplified with the alu primer PDJ34 from YAC B58C7. Primer sequence and amplification was performed as described by Nelson et al. (18). A probe for SNRPN was isolated from a brain cDNA library by PCR. Based on the sequence of the human SNRPN cDNA (11), a set of PCR primers were synthesized (SmN1, 5' AGTGTGAGTTGTACCCGAGG 3'; SmN2 5' CAGGGGAAAAAGTGACTGAG 3'). The primers were used to amplify a 1 kb cDNA fragment from a fetal brain cDNA library (Stratagene). PCR was carried out in a GenAmp PCR system 9600 (PerkinElmer/Cetus) in a total volume of $100 \mu$ l containing $2 \times 10^{7}$ pfu of the cDNA 
library, $50 \mathrm{mM} \mathrm{KCl}, 10 \mathrm{mM}$ Tris- $\mathrm{HCl}(\mathrm{pH} 8.0), 1.5 \mathrm{mM} \mathrm{MgCl}, 0.01 \%$ gelatin, $200 \mathrm{mM}$ each dNTP and 2.5 units Taq DNA polymerase. The following conditions were used: 35 cycles of denaturation $\left(95^{\circ} \mathrm{C}\right.$ for $\left.15 \mathrm{sec}\right)$, annealing $\left(58^{\circ} \mathrm{C}\right.$ for $\left.30 \mathrm{sec}\right)$ and extension $\left(72^{\circ} \mathrm{C}\right.$ for $\left.30 \mathrm{sec}\right)$.

\section{ACKNOWLEDGEMENT}

We would like to thank B. Brandt for expert technical assistence and Prof E. Passarge for continuous support. Parts of this work were supported by the Deutsche Forschungsgemeinschaft.

\section{REFERENCES}

1. Nicholls, R.D. (1993) Current Opinions in Genetics and Development 3, 445-456.

2. Mutirangura, A., Jayakumar, A., Sutcliffe, J.S., Nakao, M., McKinney, M.J., Buiting, K., Horsthemke, B., Beaudet, A.L., Chinault, A.C. and Ledbetter, D.H. (1993) Genomics. In Press.

3. Robinson, W.P., Bottani, A., Yagang, X., Balakrishman, J., Binkert, F., Mãchler, M., Prader, A. and Schinzel, A. (1991) Am. J. Hum. Genet. 49, $1219-1234$.

4. Saitoh, S., Kubota, T., Ohta., T., Jinno, Y., Niikawa, N., Sugimoto, T., Wagstaff, J. and Lalande, M. (1992) Lancet 339, 366-367.

5. Greger, V., Woolf, E., and Lalande M. (1993) Hum. Molec. Genet. 2, $921-924$.

6. Dittrich B., Robinson., W.P., Knoblauch, H., Buiting, K., Schmidt, K., Gillessen-Kaesbach, G. and Horsthemke B. (1992) Hum. Genet. 90, 313-315.

7. Örcelik, T., Leff, St. Robinson, W., Donlon, T., Lalande M., Saniines E., Schinzel, A. and Francke, U. (1992) Nature Genet. 2, 265-269.

8. Kuwano, A., Mutirangure, A., Dittrich, B., Buiting, K., Horsthemke, B., Saitoh, S., Niikawa, N., Ledbetter, S.A., Greenberg, F., Chinault, A.C. and Ledbetter, D.H. (1992) Hum. Molec. Genet. 1, 417-425.

9. Burke, D.T., Carle, G.F. and Olson M.V. (1987) Science 236, 806-812.

10. Dittrich, B., Buiting, K., Gro $\beta$ S. and Horsthemke B., in preparation.

11. Schmauss, C., Mc Allister, G., Ohosone, Y., Hardin, J.A. and Lemer, M.R. (1989) Nucleic Acids Res. 17, 1733-1743.

12. Leff St.E., Brannan, C.I., Reed, M.L., Özcelik, T., Francke, U., Copeland, N.G. and Jenkins N.A. (1992) Nature Genet. 2, 259-264.

13. Glenn, C.C., Nicholls R.D., Robinson W.P., Saitoh, S., Niikawa, N, Schinzel, A., Horsthemke B. and Driscoll D.J. (1993), Hurn. Molec. Genet. 2, $1377-1382$.

14. Carle, G.F. and Olson, M.V. (1984) Nucleic Acids Res. 12, 5647-5664.

15. Horsthemke, B., Greger, V., Bamert, H.J., Höpping, W. and Passarge, E. (1987) Hum. Genet. 76, 257-261.

16. Buiting, K., Neumann, M., Lüdecke, H.-J., Senger, G., Claussen, U., Antich, J., Passarge, E. and Horsthemke, B. (1990) Genomics 6, 521-527.

17. Donlon, T.A., Lalande, M., Wyman, A., Bruns, G. and Latt, S. A. (1986) Proc. Natl. Acad. Sci. USA 83, 4408-44115.

18. Nelson, D.L., Ledbetter, S.A., Corto, L., Victoria, M.F., Ramirez-Solis, R., Webster, T.D. and Ledbetter, D.H (1989) Proc. Natl. Acad. Sci. USA 86, $6686-6690$. 